\title{
Analysis of the asynchronous dental teleconsulting of Telehealth Brazil Networks in Minas Gerais
}

\section{Lígia Cristelli PAIXÃO(a) \\ Vanessa Andrade COSTA ${ }^{(b)}$ \\ Efigênia Ferreira e FERREIRA ${ }^{(c)}$ \\ Antônio Paulino RIBEIRO SOBRINHO(d) \\ Renata de Castro MARTINS(c)}

(a) Universidade Federal de Minas Gerais UFMG, School of Dentistry, Postgraduate Program in Dentistry, Belo Horizonte, MG, Brazil.

(b) Universidade Federal de Minas Gerais - UFMG, School of Dentistry, Scientific initiation, Belo Horizonte, MG, Brazil.

(c) Universidade Federal de Minas Gerais UFMG, School of Dentistry, Department of Social and Preventive Dentistry, Belo Horizonte, Minas Gerais, Brazil.

(d) Universidade Federal de Minas Gerais UFMG, School of Dentistry, Department of Restorative Dentistry, Belo Horizonte, Minas Gerais, Brazil.

Declaration of Interests: The authors certify that they have no commercial or associative interest that represents a conflict of interest in connection with the manuscript.

\section{Corresponding Author:}

Renata Martins

E-mail:r.c.martins@uol.com.br

hitps://doi.org/10.1590/1807-3107bor-2018.vol32.0128

Submitted: June 07, 2018

Accepted for publication: October 16, 2018

Last revision: November 08, 2018

\begin{abstract}
This cross-sectional study aimed to evaluate the asynchronous dental teleconsulting of Telehealth Brazil Networks Program in Minas Gerais. Data were collected from secondary databases of the Clinical Hospital of the Universidade Federal de Minas Gerais (CH/UFMG) and Medical School of UFMG (MS/UFMG), from July 2015 to July 2017. The variables analyzed were telehealth center, sex and profession, date and time questions and answers, response time in days, whether the issue was duly addressed, whether the teleconsulting was attended, post status, professional's satisfaction, conduct adopted after teleconsulting, dental specialty area, and type of issues. Sociodemographic data from the Intermediate Geographical Regions (IGR) of Minas Gerais, including the Municipal Human Development Index (MHDI) and Gini Index were also collected. The results were analyzed using SPSS v.22.0. In total, 3,920 teleconsulting were recorded, with increasing demand in the study period. Most were requested by dentists (93.3\%) and female professionals $(78.6 \%)$, during office hours $(78.6 \%)$, and related to general conducts $(72.1 \%)$. Almost all were attended $(99.7 \%)$, with a maximum response time of two days (75.0\%). A low feedback on satisfaction and resolution of issues (missing data of $57.2 \%$ and $70.2 \%$, respectively) was recorded. Only 5.2\% had information on whether patients were referred. The most common inquires were of issues about Pathology/ Stomatology specialties (19.0\%) and Pharmacology/Anesthesiology $(18.8 \%)$. The response occurred within the expected time, with prevalent issues in basic dental areas and general conducts. Feedback from professionals must be encouraged to allow a better analysis and improvements of the program.
\end{abstract}

Keywords: Primary Health Care; Telemedicine; Dentistry; Public Health.

\section{Introduction}

Telehealth is the long-distance exchange of information related to healthcare and health education through information and communication technologies that allow people with little or no access to care to have their needs met by specialty professionals. It includes the establishment of disease diagnosis, treatment, and prevention, besides being a powerful tool for the continuing education of general practitioners (GPs). ${ }^{1}$ 
Telehealth has the potential to reduce time to diagnosis, ${ }^{2}$ avoid unnecessary patient travel, optimize financial resources without compromising the quality of care, ${ }^{3,4,5}$ and improve the resolution of care. ${ }^{6}$ In general, telehealth has good acceptability by professionals and patients ${ }^{5}$, and enables better work conditions and less isolation of professionals working in remote areas, favoring their stay in these locations.?

Teledentistry has growing applications in dentistry, increasing access and improving health services. ${ }^{1}$ It is is used in several countries and spheres of care and is being considered a valid and feasible means of diagnosis compared to traditional ones ${ }^{8}$. However, teledentistry studies usually show no consistent research methodology and lack evidence ${ }^{1}$, since their variability hinders the generalization of findings. ${ }^{8}$ Thus, the validity of teledentistry in dental specialties requires further research. ${ }^{8}$

In Brazil, the experience with distance care and education related to health started in 2006 with the implementation of the "Telehealth" project by the Ministry of Health to strengthen and improve the resolution of Primary Health Care (PHC) ${ }^{4}$ and increase people's access to specialized services. ${ }^{2}$ It was established as the National Telehealth Program in 2007, and the program has since undergone expansions and redefinitions. ${ }^{9}$ Recently, it was renamed as the National Telehealth Program Brazil Networks. ${ }^{4}$

The program offers the clarification of issues about diagnosis and clinical procedures through a second opinion by teleconsulting: health professionals providing direct care to patients at the service (GP) can ask questions to dental specialists. The term "teleconsulting" refers to remote communication between two health professionals, and not between a health professional and a patient, since distance direct assistance to patients is not allowed in Brazil. ${ }^{10}$ Teleconsulting can be synchronous, when communication occurs in real time by messaging or videoconference, or asynchronous, by off-line messages that must be answered within 72 hours. The service, offered by telehealth centers, ${ }^{4}$ provides assistance and educational support to users., ${ }^{40}$

The teleconsulting service also includes support for laboratory tests and diagnosis and a formative second opinion: a question and answer database extracted from previous teleconsulting sessions, selected according to relevance, ${ }^{4}$ developed with the objective of bridging health services and scientific knowledge. ${ }^{10}$ Another important feature is teleeducation, which supports the training of Primary Health Units (PHU) workers. ${ }^{4}$

Since the establishment of the program, many studies have been carried out to evaluate its functioning and benefits in the treatment of patients. However, dental asynchronous teleconsulting has been little explored. Thus, this study aimed to assess the dental teleconsulting service of the National Telehealth Program Brazil Networks in Minas Gerais centers.

\section{Methodology}

This cross-sectional study used secondary databases from the two Telehealth Brazil Networks centers of Minas Gerais: the Clinical Hospital of the Federal University of Minas Gerais (CH-UFMG), which covers $91 \%$ of the state's municipalities, ${ }^{11}$ and UFMG Medical School (MS-UFMG), which covers the remaining municipalities of the state and intermunicipal centers of Brumadinho, Belo Horizonte and Contagem. The data used was from July 2015 to July 2017.

Data were extracted from asynchronous dentistry teleconsulting services, collecting the variables telehealth center (CH-UFMG or MS-UFMG), sex (male or female) and profession (dentist or others), date and time of the question and answer, response time in days, whether the issue was resolved (completely, partially or not resolved), whether teleconsulting was attended (yes or no), post status (active - requesting party has not read the answer, inactive - finalized and filed by the requesting party, or pending - not concluded by the requesting party), professional satisfaction (satisfied, indifferent or dissatisfied), conduct adopted (referral to secondary or tertiary care levels, or kept in the PHU), dentistry specialty, and type of issue (diagnosis, general conduct or system operation).

Municipalities that used teleconsulting in the period of the survey were characterized by collecting data of the Intermediate Geographical Regions (IGR) 
of Minas Gerais, ${ }^{12}$ Municipal Human Development Index (MHDI), and Gini Index of the Brazilian Institute of Geography and Statistics (IBGE). ${ }^{13}$ In 2017, a new region structure was presented by IBGE because of the economic, demographic, environmental, and political changes that occurred since the establishment of the last structure in 1990. Based on the new framework, Minas Gerais has 13 IGRs, 70 Immediate Geographical Regions, and 853 municipalities. ${ }^{12}$ The MHDI indicates three dimensions of human development: longevity, education, and income. The index adjusts the international HDI methodology to the Brazilian context using available national indicators, and is somewhat adequate to evaluate the development of Brazilian municipalities. The index varies from 0 to 1 ; the closer to 1 , the higher the human development. ${ }^{14}$ The Gini Index is used to measure the level of income distribution and varies from 0 (perfect equality) to 1 (maximum inequality). ${ }^{15}$

Teleconsulting sessions that were duplicated, did not contain questions, with incomplete information (preventing specialty classification), and with issues other than dentistry were excluded.

The results were analyzed using Statistical Package for Social Sciences Version 22.0. Quantitative data were analyzed by the Shapiro-Wilk and KolmogorovSmirnov tests $(\mathrm{p}<0.05)$. Data with a normal distribution $(p>0.05)$ were described by means and standard deviations and those without a normal distribution $(p$ $<0.05$ ) were described by medians and interquartile ranges. Categorical data were analyzed by frequency and percentage.

The Research Ethics Committees of the UFMG approved the study under protocol $\mathrm{N}^{\circ} 2.059 .173$ (CAAE 67446817.2.0000.5149). Participants' consent was not required since secondary data were collected. Access to data from each telehealth center was obtained from people responsible for the databases. Patients, professionals, and teleconsulting officers were not identified.

\section{Results}

The initial sample consisted of 4,093 teleconsulting sessions from the databases of the CH-UFMG and MS-UFMG centers. Following the exclusion criteria, 173 sessions were removed, which resulted in a final sample of 3,920 teleconsulting: 3,324 (84.8\%) from $\mathrm{CH}$ and 596 (15.2\%) from MS database and intermunicipal centers.

A growing demand for teleconsulting was noted during the analyzed period, as follows: from July to December 2015 there were 187, in 2016 there were 2,214, and from January to July 2017, 1,519.

Among professionals, dentists used the service most often $(93.3 \%)$, followed by nurses (3.6\%), oral health technicians $(1.8 \%)$, doctors $(1.1 \%)$, speech therapists $(0.1 \%)$, pharmacists $(0.025 \%)$, and social workers $(0.025 \%)$, and $66.7 \%$ of these were female. Most of the teleconsulting sessions were requested during work hours (between 08:00 a.m. and 6:00 p.m.) and consisted of general conduct issues (72.1\%).

The response to GPs showed a median of zero days, indicating a 24-hour maximum response time (IQR-25 = zero days, IQR-75 = one day). Almost all inquiries were attended (99.7\%), and $81.3 \%$ were inactive. Most of the professionals did not answer if the existing issues were responded (70.2\%), and only $20.5 \%$ said their questions were fully responded. Regarding response satisfaction level, $26.3 \%$ answered they were satisfied and $57.2 \%$ did not answer this information. The conduct taken after teleconsulting was available in only $5.2 \%$ of cases (Table 1 ).

The participating municipalities had a mean Gini index of 0.407 and MHDI of 0.654 . The IGR that most frequently used the teleconsulting service was Montes Claros (38.7\%), followed by Juiz de Fora (11.0\%). About telehealth centers, a higher demand was seen in Montes Claros at the CH-UFMG center $(44.7 \%)$ and in Barbacena (31.1\%) at the MS-UFMG center. The percentage of municipalities that made a request from the total number of municipalities in each IGR was higher in the IGR of Montes Claros (54.6\%), followed by Patos de Minas (53.0\%), and Teófilo Otoni (44.2\%). Patos de Minas (0.702) followed by Varginha (0.701) and Belo Horizonte (0.694) were the ones with the highest MHDI index, while the lowest were for Teófilo Otoni (0.614), followed by Governador Valadares $(0.626)$ and Montes Claros (0.633). For the Gini Index, higher values were seen for Ipatinga (0.427), Teófilo Otoni (0.424), and Pouso Alegre (0.424), and lower values for Uberaba (0.372), followed by Uberlândia (0.382) and Belo Horizonte (0.392) (Table 2). 
Table 1. Descriptive analysis of the dental Teleconsulting sessions carried out in Minas Gerais, Brazil in 2017.

\begin{tabular}{|c|c|c|}
\hline Variables & Absolute frequency (n) & Relative frequency $(\%)$ \\
\hline \multicolumn{3}{|l|}{ Telehealth center } \\
\hline Clinical Hospital - UFMG & 3,324 & 84.8 \\
\hline Medical School - UFMG & 596 & 15.2 \\
\hline \multicolumn{3}{|l|}{ Year } \\
\hline 2015 & 187 & 4.8 \\
\hline 2016 & 2,214 & 56.5 \\
\hline 2017 & 1,519 & 38.8 \\
\hline \multicolumn{3}{|l|}{ Professional } \\
\hline Dentist & 3,658 & 93.3 \\
\hline Others* & 262 & 6.7 \\
\hline \multicolumn{3}{|l|}{ Gender } \\
\hline Female & 2,616 & 66.7 \\
\hline Male & 1,304 & 33.3 \\
\hline \multicolumn{3}{|l|}{ Time of the day } \\
\hline Within work hours** & 3,082 & 78.6 \\
\hline Outside work hours & 781 & 19.9 \\
\hline Without information & 57 & 1.5 \\
\hline \multicolumn{3}{|l|}{ Type of issue } \\
\hline Diagnosis & 1,003 & 25.6 \\
\hline General conduct & 2,827 & 72.1 \\
\hline Service operation & 90 & 2.3 \\
\hline \multicolumn{3}{|l|}{ How was the issue responded } \\
\hline Completely & 802 & 20.5 \\
\hline Partially & 274 & 7.0 \\
\hline Not answered & 91 & 2.3 \\
\hline Without information & 2,753 & 70.2 \\
\hline \multicolumn{3}{|l|}{ Satisfaction with answer } \\
\hline Indifferent & 5 & 0.1 \\
\hline Dissatisfied & 644 & 16.4 \\
\hline Satisfied & 1,029 & 26.3 \\
\hline Without information & 2,242 & 57.2 \\
\hline \multicolumn{3}{|l|}{ Posting status } \\
\hline Active & 726 & 18.5 \\
\hline Inactive & 3,188 & 81.3 \\
\hline Pending & 6 & 0.2 \\
\hline \multicolumn{3}{|l|}{ Teleconsulting attended } \\
\hline Yes & 3,909 & 99.7 \\
\hline No & 8 & 0.2 \\
\hline Without information & 3 & 0.1 \\
\hline \multicolumn{3}{|l|}{ Conduct after teleconsulting } \\
\hline Referral to secondary health care level & 41 & 1.0 \\
\hline Referral to tertiary healthcare level & 6 & 0.2 \\
\hline Kept in PHU & 158 & 4.0 \\
\hline Without information & 3,715 & 94.8 \\
\hline
\end{tabular}

*Nurse, Doctor, Pharmacist, Oral health technician, Social worker, Speech therapist. ${ }^{* * 8: 00}$ a.m. to 6:00 p.m.. PHU: Primary Health Unit. 
Table 2. Descriptive analysis of the Intermediate Geographical Region of Minas Gerais that requested teleconsulting and the absolute and relative frequency of requests according to the Telehealth center in Minas Gerais, Brazil, 2017.

\begin{tabular}{lccccc}
\hline $\begin{array}{l}\text { Region (Total } \mathrm{n} \text { of } \\
\text { municipalities) }\end{array}$ & CH-UFMG n (\%) & MS-UFMG n (\%) & $\begin{array}{c}\text { Municipalities that } \\
\text { requested teleconsulting } \\
\text { sessions } \mathrm{n}(\%)\end{array}$ & $\begin{array}{c}\text { IDHM } \\
\text { (Mean and SD) }\end{array}$ & $\begin{array}{c}\text { Gini index } \\
\text { (Mean and SD) }\end{array}$ \\
\hline Belo Horizonte (74) & $149(4.5)$ & $113(19.0)$ & $15(20.3 \%)$ & $0.694 \pm(0.031)$ & $0.392 \pm(0.044)$ \\
Montes Claros (86) & $1487(44.7)$ & $30(5.0)$ & $47(54.6 \%)$ & $0.633 \pm(0.033)$ & $0.407 \pm(0.026)$ \\
Teófilo Otoni (86) & $339(10.2)$ & $13(2.2)$ & $38(44.2 \%)$ & $0.614 \pm(0.037)$ & $0.424 \pm(0.025)$ \\
Governador Valadares (58) & $53(1.6)$ & $25(4.2)$ & $10(17.2 \%)$ & $0.626 \pm(0.046)$ & $0.394 \pm(0.019)$ \\
lpatinga (44) & $83(2.5)$ & $2(0.3)$ & $5(11.4 \%)$ & $0.657 \pm(0.011)$ & $0.427 \pm(0.013)$ \\
Juíz de Fora (146) & $352(10.6)$ & $80(13.4)$ & $27(18.5 \%)$ & $0.658 \pm(0.032)$ & $0.401 \pm(0.022)$ \\
Barbacena (49) & $74(2.2)$ & $185(31.1)$ & $15(30.6 \%)$ & $0.675 \pm(0.060)$ & $0.412 \pm(0.026)$ \\
Varginha (82) & $220(6.6)$ & $10(1.7)$ & $19(23.2 \%)$ & $0.701 \pm(0.021)$ & $0.415 \pm(0.028)$ \\
Pouso Alegre (80) & $6(0.2)$ & $62(10.4)$ & $6(7.5 \%)$ & $0.687 \pm(0.010)$ & $0.424 \pm(0.017)$ \\
Uberaba (29) & $4(0.1)$ & $0(0.0)$ & $3(10.3 \%)$ & $0.686 \pm(0.011)$ & $0.372 \pm(0.010)$ \\
Uberlândia (24) & $50(1.5)$ & $0(0.0)$ & $8(33.3 \%)$ & $0.690 \pm(0.029)$ & $0.382 \pm(0.023)$ \\
Patos de Minas (34) & $223(6.7)$ & $31(5.2)$ & $18(53.0 \%)$ & $0.702 \pm(0.016)$ & $0.415 \pm(0.014)$ \\
Divinópolis (61) & $284(8.5)$ & $44(7.4)$ & $25(41.0 \%)$ & $0.671 \pm(0.060)$ & $0.399 \pm(0.024)$ \\
Total (n) & $3,324(100.0)$ & $595(100.0)$ & $236(27.7 \%)$ & $0.654 \pm(0.046)$ & $0.407 \pm(0.027)$ \\
\hline
\end{tabular}

Table 3. Descriptive analysis of dental teleconsulting sessions according to specialty in Minas Gerais, Brazil, 2017.

\begin{tabular}{lcc}
\hline Specialty & Absolute frequency $(\mathrm{n})$ & Relative frequency $(\%)$ \\
\hline Pathology/Oral Medicine & 745 & 19.0 \\
Pharmacology/Anesthesiology & 738 & 18.8 \\
Pediatric dentistry & 404 & 10.3 \\
Surgery & 399 & 10.2 \\
Dentistry/Prosthesis & 336 & 8.6 \\
Endodontics & 289 & 7.4 \\
Semiology & 277 & 7.1 \\
Periodontics & 232 & 5.9 \\
Occlusion/Orthodontics & 150 & 3.8 \\
Community health & 105 & 2.7 \\
Others* & 101 & 2.6 \\
More than one specialty & 78 & 2.0 \\
Biosafety & 46 & 1.2 \\
Radiology & 20 & \\
Total & 3,92 & 0.5 \\
\hline Dentalissues that & 100.0 \\
\hline
\end{tabular}

*Dental issues that did not fit into specialties, and were related to the health system, health services operation, or the professional field and the job market.

In Dentistry, the most common issues were related to Pathology/Oral Medicine (19.0\%) followed by Pharmacology/Anesthesiology (18.8\%). The "others" category concerned issues of the dental field that did not fit the specialty categories and showed a frequency of $2.6 \%$. Of these, $6.9 \%$ were related to the healthcare system, $75.2 \%$ to the health services operation, and $17.8 \%$ to the work field of professionals and the labor market (Table3). 


\section{Discussion}

Considering the focus of the Brazilian Telehealth Program in filling the gaps of the healthcare system and promote a PHC of higher quality, Dentistry is among the areas of highest number of inquiries by GPs, which is in agreement with the high prevalence of oral diseases in PHC services. ${ }^{10}$ In the selected period, 3,920 teleconsulting sessions were analyzed. A higher number of questions were made from professionals of the CH-UFMG center (84.8\%) than of the MS-UFMG and inter-municipal centers, which is compatible with their coverages. ${ }^{11}$

An increasing demand was seen for asynchronous teleconsulting in recent years, also reported in another study ${ }^{16}$. This may have been influenced by the establishment of monthly financial incentives for Telehealth centers ${ }^{17}$ that remunerate municipalities and states for the use of the program ${ }^{18}$ with a minimum number of teleconsulting sessions per month for the transfer of financial resources. ${ }^{19}$

The use of secondary databases resulted in loss of data during extraction, and this was a limitation of the study. Some teleconsulting sessions retrieved from databases were incomplete, which might represent an error in data extraction or an incomplete description of the issue by GPs. Platform data loss is a problem, as it compromises adequate monitoring of the program, besides not allowing the formulation of a proper response to the case. ${ }^{20}$

Dentists had the highest participation in the program (93.3\%), but other GPs also asked for clarifications on dental issues, indicating the existence of interdisciplinary care, in line with the integrality principle of the Brazilian Healthcare System..${ }^{10}$ Also, most of the teleconsulting $(66.7 \%)$ were done by women, which may be a reflection of a higher prevalence of female professionals in the service ${ }^{21}$ and their greater adherence to the program or a more significant concern with professional conduct by female workers.

The time of the day teleconsultings were made showed that professionals used the system outside their work hours in $19.9 \%$ of cases. This was observed in another study, in which $16 \%$ of the issues were requested at night, suggesting that teleconsulting was incorporated into the routine of professionals as a necessary tool. ${ }^{22}$ Since the program is a tool to improve the quality of PHC and equipped to ensure connectivity between the PHU and telehealth centers, ${ }^{4}$ teleconsulting should be carried out within work hours, ideally. Evening requests may have occurred due to connectivity failures or difficulty in accessing the platform during work hours, due to work overload or lack of a specific place to access the platform. ${ }^{21}$

Most issues were related to general conduct (72.1\%), with questions about treatment, monitoring, and prevention, followed by diagnosis (25.6\%), indicating difficulty among GPs in deciding about the most appropriate treatments for patients. This is reflected directly in the dentists' daily actions, which are mostly focused on clinical procedures. ${ }^{10}$ Diagnosis is the most crucial step in treatment planning and should always consider several aspects of the patient to achieve a correct conclusion, an adequate treatment planning ${ }^{23}$, and prevent issues during treatment. ${ }^{24}$

Most teleconsulting were answered within the appropriate time, with a median response time of up to one day, and $75 \%$ of them were answered within two days (48 hours), showing that teleconsultants are returning within the stipulated time (of up to $72 \mathrm{~h}$ ). ${ }^{4}$

Almost all of the teleconsulting sessions were addressed (99.7\%), indicating a highly effective service. The majority of sessions was inactive (81.3\%) and posts were finalized and filed by the applicant.

Thirty percent of the professionals that used the platform answered whether or not the teleconsulting resolved the existing issue ( $70 \%$ did not answer). Of those, $20.5 \%$ said that it was resolved entirely. Twenty-six percent were satisfied, but $57.2 \%$ of total professionals did not respond to the level of satisfaction item, showing low feedback from GPs. ${ }^{20}$ These results are different from other studies that found high rates of resolved issues ${ }^{22,25}$ and high satisfaction with the service. ${ }^{25}$ Since the Telehealth program aims to provide quality information to GPs and considering that ideally all policies must be evaluated continuously on their effectiveness and improvement needs, the missing information is a limitation of this study as it hindered the evaluation process. Thus, it is necessary to raise the awareness towards the importance of professionals feedback. 
No information was available for $94.8 \%$ of the cases whether patients were referred after the teleconsulting. Of the cases with that information, $4 \%$ of patients remained at the PHU and 1.2\% were referred to secondary or tertiary care levels. Again, the lack of feedback prevents an adequate evaluation of the program in PHC. Telehealth has been suggested to be effective in avoiding unnecessary referral of patients ${ }^{22,25}$ and a supporting tool to the referral and counter-referral system. Patient referrals are often made due to the professional's perceived unpreparedness when faced with alleged complex conditions, leading to the overcrowding of specialized health services, reducing the admission of new cases or affecting the prioritization of the most severe ones. ${ }^{26}$ Thus, the possibility of integrating the teleconsulting system with the referral system might be an interesting strategy.

The demand for teleconsulting was more significant for the IGR of Montes Claros at the CH-UFMG and Barbacena at MS-UFMG. This result is likely related to the distribution of municipalities and coverage of each center.

It has been observed that municipalities with lower MHDI are the ones that most often accessed the teleconsulting system, suggesting a direct relationship with a greater need for support. ${ }^{22}$ The present study corroborates other findings showing that the IGRs that most demanded teleconsulting services were Montes Claros and Teófilo Otoni, which are regions with the worst indexes in Minas Gerais (lower MHDI and higher Gini Index). ${ }^{13}$ In addition, when considering only the participant municipalities of Uberaba, Uberlândia, and Varginha (IGR with better indexes), ${ }_{1}^{13}$ a lower average MHDI was seen when compared to the Minas Gerais state data. ${ }^{13}$ However, Montes Claros and Teófilo Otoni, which requested teleconsulting, had better indexes compared to data of the whole region..$^{13} \mathrm{~A}$ lower Gini Index was also observed for all other IGRs compared to the Minas Gerais state data, ${ }^{13}$ suggesting the participation of municipalities with low inequality conditions.

Several factors can influence the adherence to the program, such as service structure, internet speed and signal, and experience of professionals in the use of technology. ${ }^{27}$ Furthermore, some professionals may have difficulty in admitting the need for a second opinion..$^{28}$ Therefore, it is necessary to break the prejudice habit concerning seeking the opinion of co-workers. ${ }^{16}$ Health professional should be trained and encouraged to use the Telehealth system and PHU and services managers should encourage this type of care. ${ }^{20,21}$

The most common fields of dentistry were Pathology/Oral Medicine (19.0\%) and Pharmacology/ Anesthesiology (18.8\%), suggesting a weak training of professionals in the basic areas of dentistry. Periodic training should be provided to professionals through continuing education programs to fill the gaps left by undergraduate courses ${ }^{16}$ and basic courses should receive greater emphasisin these areas.

In the "others" category, a frequent demand was for issues concerning the healthcare system (productivity entries and procedural codes), the operation of the service (dental charts, certificates, home visits, procedures performed at the PHU, oral health indicators, patient's absence, selection of teleconsultants, and, especially, patient's referral), and the professional field and labor market. This indicates the professionals' unpreparedness and lack of knowledge about the functioning of the public health service and the system in which they operate.

\section{Conclusion}

The demand for dental teleconsulting has been increasing, and the system provides a quick response to GPs. Professionals feedback about satisfaction and resolution of teleconsulting was low. The input from professionals must be encouraged for a better understanding of the impact of teleconsulting as a support system for the PHC, for the improvement of the program.

The high prevalence of teleconsulting about the basic areas of dentistry and general conducts suggest a lack of professional training and difficulty in deciding on the patient's treatment. Periodic training should be provided to professionals through continuing education programs, and greater emphasis should 
be given to these areas in undergraduate courses to have professionals better trained to establish adequate diagnoses and provide comprehensive treatment to patients.

\section{References}

1. Daniel SJ, Kumar S. Teledentistry: a key component in access to care. J Evid Based Dent Pract. 2014 Jun;14 Suppl:201-8. https://doi.org/10.1016/i.jebdp.2014.02.008

2. Alkmim MB, Figueira RM, Marcolino MS, Cardoso CS, Abreu MP, Cunha LR et al. Improving patient access to specialized health care: the Telehealth Network of Minas Gerais, Brazil. Bull World Health Organ. 2012 May;90(5):373-8. https://doi.org/10.2471/BLT.11.099408

3. Santos AF, Haddad SC, Alves HJ, Torres RM, Souza C, Melo MC. Evaluating the experience of training through videoconferences in primary care. Telemed J E Health. 201 la Nov;17(9):722-6. https://doi.org/10.1089/tmi.2011.0041

4. Ministério da Saúde (BR). Secretaria de Atenção à Saúde. Coordenação Nacional do Progarma Telessaúde Brasil Redes. Nota Técnica N 50/ 2015. Diretrizes para oferta de atividades do Programa Nacional Telessaúde Brasil Redes. Brasília, DF Ministério da Saúde; 2015 [cited 2016 nov 21]. Available from: http://189.28.128.100/dab/ docs/portaldab/notas_tecnicas/Nota_Tecnica_Diretrizes_ Telessaude.pdf

5. Irving M, Stewart R, Spallek H, Blinkhorn A. Using teledentistry in clinical practice, an enabler to improve access to oral health care: a qualitative systematic review. J Telemed Telecare. 2018 Apr;24(3):129-46. https://doi.org/10.1177/1357633X16686776

6. Haddad AE, Bönecker M, Skelton-Macedo MC. Research in the field of health, dentistry, telehealth and teledentistry. Braz Oral Res. 2014;28(1):1-2. https://doi.org/10.1590/1807-3107BOR-2014.vol28.0001

7. Campos FE, Haddad AE, Wen CL, Alkmin MB, Cury PM. The national telehealth program in Brazil: an instrument of support for primary health care. Latin Am J Telehealth. $2009 ; 1(1): 39-66$.

8. Alabdullah JH, Daniel SJ. A systematic review on the validity of teledentistry. Telemed J E Health. 2018 Aug;24(8):639-48. https://doi.org/10.1089/tmi.2017.0132

9. Ministério da Saúde (BR). Portaria N².546, de 27 de outubro de 2011. Redefine e amplia o Programa Telessaúde Brasil, que passa a ser denominado Programa Nacional Telessaúde Brasil Redes (Telessaúde Brasil Redes). Diário Oficial União. 28 out 2011.

\section{Acknowledgments}

This study was supported by the Coordenação de Aperfeiçoamento de Pessoal de Nível Superior (CAPES/PROEX).

10. Haddad AE, Skelton-Macedo MC, Abdala V, Bavaresco

C, Mengehel D, Abdala CG et al. Formative second opinion: qualifying health professionals for the unified health system through the Brazilian Telehealth Program. Telemed J E Health. 2015 Feb;21(2):138-42. https://doi.org/10.1089/tmi.2014.0001

11. Hospital das Clínicas - UFMG. Centro de Telesaúde. Cobertura. Belo Horizonte: Centro de Telessaúde Hospital das Clínicas; 2015 [cited 2016 nov 24]. Available from: http:// www.telessaude.hc.ufmg.br/quem-somos/cobertura/

12. Instituto Brasileiro de Geografia e Estatística. Divisão Regional do Brasil em Regiões Geográficas Imediatas e Regiões Geográficas Intermediárias. Rio de Janeiro: Instituto Brasileiro de Geografia e Estatística; 2017 [cited 2018 may 4]. Available from: https://www.ibge.gov.br/apps/regioes_geograficas/

13. Instituto Brasileiro de Geografia e Estatística. Cidades. Rio de Janeiro: Instituto Brasileiro de Geografia e Estatística; 2016 [cited 2016 nov 22]. Available from: http://cidades.ibge.gov. $\mathrm{br} / \mathrm{xtras} / \mathrm{uf}$. php? lang $=\&$ coduf $=31$ \&search $=$ minas - gerais

14. PNUD Brasil. O que é o IDHM. Brasília, DF: Programa das Nações Unidas para o Desenvolvimento no Brasil; 2016 [cited 2016 nov 24]. Available from: http://www.undp.org/content/ $\mathrm{brazil/pt/home/idh0/conceitos/o-que-e-o-idhm.html}$

15. Instituto Brasileiro de Geografia e Estatística. Indicadores sociais mínimos: conceitos. Brasília, DF: Instituto Brasileiro de Geografia e Estatística; 2010 [cited 2018 mar 10]. Available from: https://ww2.ibge.gov.br/home/estatistica/populacao/ condicaodevida/indicadoresminimos/default_minimos.shtm

16. Correia AD, Dobashi BF, Gonçalves CC, Monreal VR, Nunes EA, Haddad PO et al. Teleodontologia no programa nacional telessaúde Brasil redes: relato da experiência em Mato Grosso do Sul. ABENO. 2014;14(1):17-29. https://doi.org/10.30979/rev.abeno.v14i1.96

17. Ministério da Saúde (BR). Portaria N²859, de 29 de dezembro de 2014. Institui o incentivo financeiro de custeio mensal destinado aos Núcleos Intermunicipais e Estaduais de Telessaúde do Programa Nacional de Telessaúde Brasil Redes na Atenção Básica, e dá outras providências. Diário Oficial União. 30 dez 2014.

18. Maldonado JM, Marques AB, Cruz A. Telemedicine: challenges to dissemination in Brazil. Cad Saude Publica. 2016 Nov;32(32 Suppl 2):e00155615. https://doi.org/10.1590/0102-311X00155615 
19. Minas Gerais. Secretaria de Estado de Saúde. Resolução SES/MG No 5.246, de 13 de abril de 2016. Estabelece as normas gerais de adesão, execução, acompanhamento, controle e avaliação da concessão de incentivo financeiro para cofinanciamento da Atenção Primária à Saúde para o exercício de 2016. Minas Gerais: Secretaria de Estado de Saúde; 2016[cited 2018 apr 21], Available from http://www.saude.mg.gov.br/sobre/institucional/ resolucoes/documents?by_year=0\&by_month $=\& b y$ format $=\&$ category_id $=\&$ ordering $=\& q=$ RESOLU $\%$ C $3 \% 87 \%$ $\mathrm{C} 3 \% 83 \mathrm{O}+\mathrm{SES} \% 2 \mathrm{FMG}+\mathrm{N} \% \mathrm{C} 2 \% \mathrm{BA}+5.246 \% 2 \mathrm{C}+\mathrm{DE}+13+$ $\mathrm{DE}+\mathrm{ABRIL}+\mathrm{DE}+2016$

20. Melo MD, Nunes MV, Resende RF, Figueiredo RR, Ruas SS, Santos AF et al. Belo Horizonte - Telehealth: incorporation of teleconsultations in a health primary care system. Telemed J E Health. 2018 Aug;24(8):631-8. https://doi.org/10.1089/tmi.2017.0165

21. Rezende EJ, Tavares EC, Alves HJ, Santos AF, Melo MC. Teleconsultations in public primary care units of the city of belo horizonte, Brazil: profile of patients and physicians. Telemed J E Health. 2013 Aug;19(8):613-8. https://doi.org/10.1089/tmi.2012.0179

22. Marcolino MS, Alkmim MB, Assis TG, Sousa LA, Ribeiro AL. [Telehealth support for primary health care in remote municipalities in the state of Minas Gerais, Brazil]. Rev Panam Salud Publica. 2014 May-Jun;35(5-6):345-52. Português.
23. Farid $H$, Khan FR, Pasha L, Shinwari MS. Are pulp sensibility tests still sensible? J Ayub Med Coll Abbottabad. 2015 OctDec;27(4):874-7.

24. SIVAKUMAR A. THANGASWAMY V, RAVI V. Treatment planning in conservative dentistry. J Pharm Bioallied Sci. 2012;4(2):6-9.

25. Harzheim E, Gonçalves MR, Umpierre RN, da Silva Siqueira AC, Katz N, Agostinho MR, et al. Telehealth in Rio Grande do Sul, Brazil: bridging the Gaps. Telemed J E Health. 2016 Nov;22(11):938-44. https://doi.org/10.1089/tmj.2015.0210 26. Batista J, Furtado MV, Katz N, Agostinho MR, Silva Neto $B$, Harzheim E et al. Telemedicine-supported transition of stable coronary artery disease patients from tertiary to primary health care facilities: protocol for a randomized noninferiority trial. BMC Health Serv Res. 2016 Jul;16(227):227. https://doi.org/10.1186/s12913-016-1469-4

27. Souza CH, Morbeck RA, Steinman M, Hors CP, Bracco $\mathrm{MM}$, Kozasa $\mathrm{EH}$ et al. Barriers and benefits in telemedicine arising between a high-technology hospital service provider and remote public healthcare units: a qualitative study in Brazil. Telemed J E Health. 2017 Jun;23(6):527-32. https://doi.org/10.1089/tmi.2016.0158

28. Santos AF, Santos SF, Melo MC, Silva EM, Reis GA, Souza C. Telehealth in primary healthcare: an analysis of Belo Horizonte's experience. Telemed J E Health. 2011b JanFeb;17(1):25-9. https://doi.org/10.1089/tmi.2010.0099 